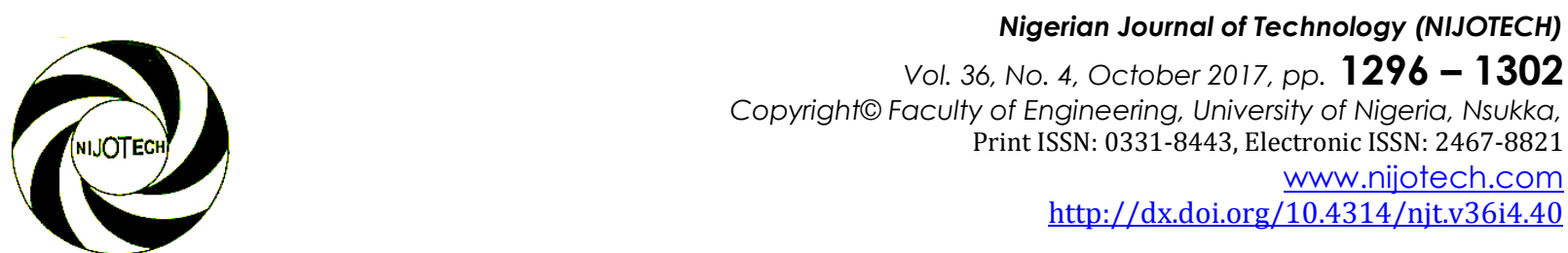

\title{
COMPARATIVE ANALYSIS OF RAINFALL IDF EQUATION TYPES FOR PREDICTING RAINFALL INTENSITY IN SOUTHERN NIGERIA
}

\author{
I. Ologhadien ${ }^{1}$ and I. L. Nwaogazie, ${ }^{2}$ * \\ 1, Dept. of Civil Engr'G, Rivers State Univ. of Sc. \& TeCh., NkPolu, Port Harcourt, Rivers State, Nigeria \\ 2, Dept. of Civil and Env. Engr'G, Univ. of Port Harcourt, Choba, Port Harcourt, Rivers State, NiGERIA \\ E-mail addresses: ${ }^{1}$ itolima2016@gmail.com,2 ifynwaogazie@yahoo.com
}

\begin{abstract}
This paper compared the differences and similarities in the rainfall intensities predicted by four standard IDF equations for return periods between 5 and 40 years and for storm durations between 15 and 30 minutes. The empirical models employed for comparison on the development of standard IDF equations using historic data for Benin, Calabar, Port Harcourt, Onitsha and Warri meteorological stations, all in Southern Nigeria were available in literature. The strength and weakness of the different models were assessed using the mean \pm standard deviation as range between intensities estimated for 5 and 40 years, and percent relative error between the observed and predicted rainfall intensities as performance criteria. The results obtained showed that there were significant differences in the rainfall intensities as predicted by the equation types. However, the IDF types-1 and 2 equations displayed lower range values in intensities for all returned periods. Types-1 and 2 equations predicted the lowest relative error of less than or equal to $6 \%$ in all stations considered. Because IDF studies are associated with hydrologic extremes, both types-1 and 2 equations are therefore recommended for hydrologic design of flood control structures. The study has advanced the understanding of the equations and further insight in their utility as hydrologic design tools.
\end{abstract}

Keywords: Rainfall, IDF models, Intensity-Duration-Frequency, Equation types, Southern Nigeria.

\section{INTRODUCTION}

The rainfall Intensity-Duration-Frequency relationship must be known before the hydrologic design of culverts, levees, drainage, ditches, urban storm-drain system, airport drainage structures and small dams can be designed accurately. Rainfall Intensity-DurationFrequency (IDF) equation describes rainfall intensity as a function of duration for a given return period. It is an important parameter for the design of storm management facilities. Several organizations and researchers had expressed IDF relationship using different equation types without a comparative study to contrast them.

Froehlich [1] presented four standard forms of rainfall Intensity equation types which are used globally for the calibration of IDF relationships. These equation types contain parameters which ranges between 2 and 4 and these parameters are used to characterize the equation type. The equation parameters represent the influence of climate and physiographic features of the catchment on rainfall. One of the earliest IDF equation is the socalled Ministry of Health formula [2]. It contains two parameters, hence it is called equation type-2 IDF equation. Wenzel [3] provided coefficients for number of cities in United States for equation type-2 for return period of 10 years. Texas Department of Transportation [4] hydraulic design manual has equation type-3 (3-parameter equation) for use in its counties for return period of 2 to 100 years. Awokola [5] derived IDF equation using type-4 (4-parameter IDF equation) for selected cities in Southern Nigeria. Nwaogazie and Duru [6], Nwaogazie and Uba [7] and; Nwaogazie and Okonkwo [8] developed a 2-paramter equation type for Port Harcourt, Eket and Abakiliki cities respectively. Ologhadien [9] also derived 4parameter IDF model for Port Harcourt city. Ogarekpe [10] developed and compared exponential logarithmic and power-law types of IDF models for Calabar and recommended the logarithmic model for sizing and forecasting of relevant hydraulic structures in Calabar. The logarithmic model is a two-parameter form of IDF equation. Udomboso and Amahia [11] conducted a comparative analysis of rainfall prediction using statistical neural network and classical linear 
regression models to estimate rainfall events in Ibadan, Nigeria from 1971 - 2003. The equation form employed in their study [11] is different from the standard IDF forms used in this study. Al Hassoun [12] developed an empirical formula to estimate rainfall intensity in Riyadh region of Saudi Arabia. The empirical formula derived is of equation type- 4 without the " $b$ " parameter. The effect of neglecting " $b$ " parameter, reduces the equation type to threeparameter equation.

Okonkwo and Mbajiorgu [13] carried out IDF analysis for seven cities in South Eastern Nigeria but the results were presented in statistical and graphical forms. Other contributors to IDF modeling are Brenard [14] for rainfall intensity formulas, Eze [15] for rainfall intensity and energy on gully development in northeastern part of Enugu State in Nigeria; and El-Sayed [16] for intensities duration-frequency curves for ungauged sites.

The global IDF modeling had followed different equation types without a study that had compared and contrasted them. This comparative study is the purpose of this paper. The study was conducted using the IDF equations derived by Ologhadien and Nwaogazie [17] in a previous work. The predictions were carried out on return period basis for time of concentrations (durations) of 15, 20, 25 and 30 minutes and return periods of 5-, 10-,15-,20-,25-,30,35-, and 40 years. The study was designed to deepen the understanding and utility of these equations in the establishment of design-storm volumes. A design storm is a precipitation (rainfall) event used as basis for hydrologic design of hydraulic structures. The return period and time of concentration (duration) are important independent variables for the estimation of rainfall intensity using IDF relationship. It has been recommended that for well-developed areas with relatively flat slopes, the time of concentration ranges between 10 to 20 minutes, while the common practice is to use storm events having a return period of once every 2 to 10 years for the design of storm sewers in residential areas, and a return period of 10 to 30 years for commercial and high-value districts. Thus, this comparative study is based on rainfall durations of 10 to 30 minutes, and return periods of 5 to 40 years.

\section{MATERIALS AND METHODS}

Historic rainfall data (amount, $\mathrm{mm}$ and duration, hour) for Benin City $\left(5.20^{\circ} \mathrm{N}\right.$ and $5.37^{\circ} \mathrm{E}$ ) (31 years); Calabar $\left(4.59^{\circ} \mathrm{N}\right.$ and $\left.8.20^{\circ} \mathrm{E}\right)$ (21 years); Port Harcourt $\left(4.46^{\circ} \mathrm{N}\right.$ and $\left.7.01^{\circ} \mathrm{E}\right)\left(23\right.$ years); Warri $\left(5.13^{\circ} \mathrm{N}\right.$ and $\left.5.45^{\circ} \mathrm{E}\right)(26$ years) and Onitsha $\left(6.08^{\circ} \mathrm{N}\right.$ and $\left.6.47^{\circ} \mathrm{E}\right)$ (17 years) were collected and analyzed from FORM MET 141 (Tabulation of Autographic Rainfall Gauge Records).
The data (rainfall amounts and durations) were obtained from Nigerian Meteorological Department (NIMET), Oshodi Lagos, Nigeria. The authors in an earlier work [17] used the data to derive "Rainfall Intensity-Duration-Frequency Models. These models formed the basis of the comparative analyses.

The present paper seeks to undertake analytical comparisons of rainfall intensity predictions of the equation types in order to determine which one is most suitable in our geographical setting. Statistical analyses of IDF predictions on equation type were performed using IBM SPSS Statistics 2.0. Prior to analysis, input files were prepared for each station by pairing the equation type predictions on rainfall duration for various return periods. Thus, for each rainfall duration, say 15 minutes, the four equations were adopted to predict the rainfall intensities, and so on for other durations. Beginning with a return period of 10 years, the process continued for all the return periods considered.

The F-Statistic tests the significance of return period, for given duration on equation type via the rainfall intensities predicted. This test is based on linear independent pairwise comparisons among the estimated marginal means. The F-values are significant if $\mathrm{F}<0.05$; that means there are significant differences between predicted rainfall Intensities at 5\% level of probability.

The performances were evaluated using the mean \pm standard deviation as range between the rainfall intensities estimated for 5 and 40 years. For a given model and various return periods, rainfall intensity values were computed with corresponding standard deviation and that formed the basis for model performance comparison. The range was computed for each equation across the stations. The criterion adopted is that the lower the range, the closer the differences between the values predicted for 5 and 40 years, respectively. It implies that the particular equation type performed better across the stations and suitability was assessed by considering the ranges. The ranges between the highest and lowest values were plotted graphically using MS Excel. The relative error between the measured intensity and equation type predicted intensity was determined for each return period as follows:

$$
\text { percent relative error }=\frac{I_{p i}-I_{m i}}{I_{m i}} \times 100
$$

In (1), $I_{p i}$ is equation Prediction Intensity; and $I_{m i}$ is the Measured Intensity. The average of the absolute values of the errors and the standard deviation of absolute errors for each station were calculated. 


\section{RESULTS AND DISCUSSION}

\subsection{Results}

The standard IDF equation types/calibrated equation parameters, and, predicted rainfall intensities at various return periods and storm durations are as shown in Tables 1, 2 and 3, respectively. Figures 1a 1e show the performances of the four equation types in terms of rainfall intensity predictions.

Table 1: Standard IDF Equation Types and Calibrated Parameters at various Return Periods

\begin{tabular}{|c|c|c|c|c|c|c|c|}
\hline \multirow{2}{*}{$S / N$} & \multirow{2}{*}{$\begin{array}{l}\text { Equation } \\
\text { Type }\end{array}$} & \multirow{2}{*}{ Parameters } & \multicolumn{5}{|c|}{ Return Period $(\mathrm{T})$} \\
\hline & & & $T=10 \mathrm{yr}$ & $T=15 y r$ & $20 \mathrm{yr}$ & $25 \mathrm{yr}$ & $30 y r$ \\
\hline \multicolumn{8}{|c|}{ Benin City Station } \\
\hline 1 & $\mathrm{i}=\frac{a_{1}}{b_{1}+D}$ & $a_{1}, b_{1}$ & $5513.26,50.31$ & $6131.74,51.56$ & $6564.93,52.89$ & $\begin{array}{l}6898.95 \\
52.89\end{array}$ & $7171.26,53.74$ \\
\hline 2 & $\mathrm{i}=\frac{a_{2}}{D^{c 2}}$ & $\mathrm{a}_{2}, \mathrm{C}_{2}$ & $372.61,0.545$ & $426.35,0.556$ & $463.84,0.552$ & $492.80,0.559$ & $516.06,0.561$ \\
\hline 3 & $\begin{array}{c}\mathrm{i}= \\
\frac{a_{3}}{\left(b_{3}+D\right)^{c 3}}\end{array}$ & $a_{3}, b_{3}, c_{3}$ & $\begin{array}{l}6167.3 \\
52,1.076\end{array}$ & $\begin{array}{l}7073.83 \\
52,1.076\end{array}$ & $7745.8,52,1.068$ & $\begin{array}{l}8242,52 \\
1.076\end{array}$ & $\begin{array}{l}8644.49 \\
52,1.076\end{array}$ \\
\hline 4 & $\mathrm{i}=\frac{C T^{m}}{(b+D) n}$ & $c, m, b$ and $n$ & $\begin{array}{c}2675.9, \\
0.346,52 \text { and } \\
1.068 \\
\end{array}$ & $\begin{array}{c}2675.9,0.346,52 \\
\text { and } 1.068\end{array}$ & $\begin{array}{c}2675.9,0.346,52 \\
\text { and } 1.068\end{array}$ & $\begin{array}{c}2675.9, \\
0.3464,52 \\
\text { and } 1.068\end{array}$ & $\begin{array}{c}2675.9,0.3464, \\
52 \text { and } 1.068\end{array}$ \\
\hline \multicolumn{8}{|c|}{ Calabar Station } \\
\hline 1 & $\mathrm{i}=\frac{a_{1}}{b_{1}+D}$ & $a_{1}, b_{1}$ & $5240.34,50.74$ & $5737.77,48.52$ & $6082.82,47.52$ & $\begin{array}{l}6351.05 \\
46.35\end{array}$ & $6586.47,46.06$ \\
\hline 2 & $\mathrm{i}=\frac{a_{2}}{D^{c 2}}$ & $a_{2}, c_{2}$ & $348.37,0.534$ & $406,53,0.545$ & $447.49,0.551$ & $479.26,0.555$ & $505.12,0.558$ \\
\hline 3 & $\begin{array}{c}\mathrm{i}= \\
\frac{a_{3}}{\left(b_{3}+D\right)^{c 3}}\end{array}$ & $a_{3}, b_{3}, c_{3}$ & $\begin{array}{c}3140.50 \\
0.9096\end{array}$ & $\begin{array}{l}3764.45 \\
50,0.926\end{array}$ & $\begin{array}{l}4249.50 \\
50,0.935\end{array}$ & $\begin{array}{l}4611.13 \\
50,0.941\end{array}$ & $\begin{array}{l}4906.70 \\
50,0.946\end{array}$ \\
\hline 4 & $\mathrm{i}=\frac{C T^{m}}{(b+D) n}$ & $c, m, b$ and $n$ & $\begin{array}{c}1050.28 \\
0.455,50 \text { and } \\
0.930\end{array}$ & $\begin{array}{c}1050.27 \text {, } \\
0.455,50 \text { and } \\
0.930\end{array}$ & $\begin{array}{c}1050.27 \text {, } \\
0.455,50 \text { and } \\
0.930\end{array}$ & $\begin{array}{c}1050.27, \\
0.455,50 \text { and } \\
0.930\end{array}$ & $\begin{array}{c}1050.27 \text {, } \\
0.455,50 \text { and } \\
0.930\end{array}$ \\
\hline \multicolumn{8}{|c|}{ Port Harcourt } \\
\hline 1 & $\mathrm{i}=\frac{a_{1}}{b_{1}+D}$ & $a_{1}, b_{1}$ & $4676.15,22.26$ & $5127.51,20.36$ & $5442.3,19.12$ & $\begin{array}{c}5787.74, \\
20.26 \\
\end{array}$ & $5889.95,17.93$ \\
\hline 2 & $\mathrm{i}=\frac{a_{2}}{D^{c 2}}$ & $a_{2}, c_{2}$ & $551.83,0.620$ & $673.19,0.638$ & $760.10,0.650$ & $826.72,0.655$ & $881.58,0661$ \\
\hline 3 & $\begin{array}{c}\mathrm{i}= \\
\frac{a_{3}}{\left(b_{3}+D\right)^{c 3}}\end{array}$ & $a_{3}, b_{3}, c_{3}$ & $\begin{array}{l}5506.83 \\
45,1.01\end{array}$ & $\begin{array}{l}7071.67 \\
45,1.031\end{array}$ & $8201.4,45,1.046$ & $\begin{array}{l}9095.72 \\
45,1.056\end{array}$ & $\begin{array}{l}9833.23 \\
45,1.064\end{array}$ \\
\hline 4 & $\mathrm{i}=\frac{C T^{m}}{(b+D) n}$ & $c, m, b$ and $n$ & $\begin{array}{c}1063.45, \\
0.591,45, \text { and } \\
0.991\end{array}$ & $\begin{array}{c}1063.45,0.591 \\
45, \text { and } 0.991\end{array}$ & $\begin{array}{c}1063.45,0.591 \\
45, \text { and } 0.991\end{array}$ & $\begin{array}{c}1063.45, \\
0.591,45, \text { and } \\
0.991\end{array}$ & $\begin{array}{c}1063.45,0.591 \text {, } \\
45 \text {, and } 0.991\end{array}$ \\
\hline \multicolumn{8}{|c|}{ Warri } \\
\hline 1 & $\mathrm{i}=\frac{a_{1}}{b_{1}+D}$ & $a_{1}, b_{1}$ & $6826.44,90.15$ & $7495.35,89.27$ & $7945.04,88.70$ & $\begin{array}{l}8327.74 \\
88.76 \\
\end{array}$ & $8621.88,88.36$ \\
\hline 2 & $\mathrm{i}=\frac{a_{2}}{D^{c 2}}$ & $a_{2}, c_{2}$ & $178.67,0.391$ & $265.10,0.40$ & $223.53,0.405$ & $237.78,0.408$ & $249.37,0.411$ \\
\hline 3 & $\begin{array}{c}\mathrm{i}= \\
\frac{a_{3}}{\left(b_{3}+D\right)^{c 3}}\end{array}$ & $a_{3}, b_{3}, c_{3}$ & $\begin{array}{c}526.45 \\
250.5806\end{array}$ & $968.68,25,0.679$ & $951.9,25,0.670$ & $\begin{array}{c}925.07,25 \\
0.6503\end{array}$ & $\begin{array}{c}1001.9,25 \\
0.664\end{array}$ \\
\hline 4 & $\mathrm{i}=\frac{C T^{m}}{(b+D) n}$ & $c, m, b$ and $n$ & $\begin{array}{c}203,05,0.465 \\
25 \text { and } 0.635\end{array}$ & $\begin{array}{c}203.06,0.465,25 \\
\text { and } 0.635\end{array}$ & $\begin{array}{l}203.06,0.465,25 \\
\text { and } 0.635\end{array}$ & $\begin{array}{l}203.06,0.465 \\
25 \text { and } 0.635\end{array}$ & $\begin{array}{c}203.06,0.465 \\
25 \text { and } 0.635\end{array}$ \\
\hline
\end{tabular}

Source: Ologhadien and Nwaogazie [17], \pm for equation tyoe "D" represents duration 
The range in each equation type are plotted on station basis. The rainfall intensities predicted by the equations increased with increasing return period (Table 2), while the rainfall intensities decreased with increasing duration or time of concentration (Table 3). A similar trend was observed for the relationship between equation type and rainfall intensities (Table 4).

For Benin station as an example, the range computed for equation type- 1 is $85.83 \mathrm{~mm} / \mathrm{hr}$, equation type- 2 as $43.32 \mathrm{~mm} / \mathrm{hr}$; and equation type-3 - 49.63mm/hr; equation type- $4-49.78 \mathrm{~mm} / \mathrm{hr}$. In terms of inequality, EQ1 (IDF type-1) > EQ2 (IDF type-2) > EQ4 (IDF type4) $>$ EQ3 (IDF type-3). The inequality also holds for other stations except Onitsha which has small discrepancy, probably due to its physiographic setting. The percent relative error between equation types predicted rainfall intensities and measured rainfall intensities are in Figures 2 - 5. The graphs show that equation types- 1 and 2 produced the lowest percent relative error of less than or equal to $6 \%$ for all the stations.

Table 2: Predicted rainfall Intensities at various Return Periods

\begin{tabular}{|c|c|c|c|c|c|c|c|c|c|}
\hline \multirow[t]{2}{*}{ Statior } & & \multicolumn{8}{|c|}{ Return Period, years } \\
\hline & & 5 & 10 & 15 & 20 & 25 & 30 & 35 & 40 \\
\hline \multirow{2}{*}{$\begin{array}{l}. \frac{c}{\frac{D}{D}} \\
\stackrel{\infty}{\infty}\end{array}$} & $\begin{array}{l}\text { Rainfall } \\
\text { intensity }\end{array}$ & $52.41 \pm 9.07^{\mathrm{h}}$ & $67.15 \pm 9.67^{g}$ & $75.58 \pm 9.84^{\dagger}$ & $81.69 \pm 9.80^{\mathrm{e}}$ & $86.95 \pm 9.60^{d}$ & $90.79 \pm 9.65^{c}$ & $94.26 \pm 10.24^{b}$ & $96.84 \pm 10.28^{a}$ \\
\hline & $95 \%$ C.I & $49.30-55.52$ & $64.03-70.26$ & 72.46-78.69 & $78.58-84.80$ & 83.84-90.06 & 87.68-93.90 & $91.15-97.37$ & 93.73-99.95 \\
\hline \multirow{2}{*}{$\frac{\frac{0}{\mathbb{J}}}{\widetilde{J}}$ స } & $\begin{array}{l}\text { Rainfall } \\
\text { intensity }\end{array}$ & $55.83 \pm 15.99^{h}$ & & $74.28 \pm 9.07^{\dagger}$ & & $86.84 \pm 9.56^{d}$ & $91.56 \pm 10.03^{c}$ & $95.56 \pm 10.54^{b}$ & $99.40 \pm 11.36^{a}$ \\
\hline & $95 \%$ C.I & $55.55-56.11$ & $64.72-65.29$ & 73.99-74.56 & $80.96-81.53$ & $86.66-87.22$ & $91.27-91.84$ & 95.28-95.85 & $99.12-99.69$ \\
\hline \multirow{2}{*}{ 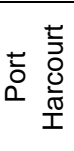 } & $\begin{array}{l}\text { Rainfall } \\
\text { intensity }\end{array}$ & $59.72 \pm 14.08^{h}$ & $83.59 \pm 18.20^{9}$ & $96.22 \pm 19.32^{f}$ & $108.66 \pm 20.35^{\mathrm{e}}$ & $116.68 \pm 19.44^{d}$ & $122.85 \pm 27.19^{c}$ & $131.78 \pm 22.63^{b}$ & $137.35 \pm 23.82^{a}$ \\
\hline & $95 \%$ C.I & $58.10-61.33$ & $81.97-85.20$ & $94.61-97.84$ & 107.05-110.27 & $115.07=118.30$ & $\begin{array}{l}121.23- \\
124.46\end{array}$ & 130.16-133.39 & $135.72-138.93$ \\
\hline$\sum^{\frac{5}{3}}$ & $\begin{array}{l}\text { Rainfall } \\
\text { intensity }\end{array}$ & $42.98 \pm 5.19^{h}$ & $55.60 \pm 5.52^{g}$ & $65.09 \pm 6.82^{f}$ & $70.64 \pm 6.67^{e}$ & $74.34 \pm 7.25^{d}$ & $78.34 \pm 7.25^{\mathrm{c}}$ & $81.77 \pm 9.51^{b}$ & $82.89 \pm 11.15^{a}$ \\
\hline \multirow{2}{*}{$\stackrel{\infty}{.=}$} & $\begin{array}{l}\text { Rainfall } \\
\text { Intensity }\end{array}$ & $52.01 \pm 10.57^{g}$ & $66.09 \pm 8.98^{f}$ & $74.09 \pm 7.88^{\mathrm{e}}$ & $85.92 \pm 7.97^{c}$ & $89.47 \pm 8.46^{b}$ & $97.77 \pm 11.51^{\mathrm{a}}$ & $81.77 \pm 9.50^{d}$ & $82.79 \pm 11.15^{c}$ \\
\hline & $95 \%$ C.I & $51.73-52.30$ & 65.89-66.37 & 73.87-74.43 & $85.63-86.20$ & $89.19-89.76$ & $97.49-98.06$ & $81.49-82.06$ & 82.51-83.07 \\
\hline
\end{tabular}

a-h indicate statistically significant difference, $\mathrm{CI}=$ confident interval

Table 3: Predicted Rainfall Intensities at various Durations

\begin{tabular}{|c|c|c|c|c|c|}
\hline \multirow[t]{2}{*}{ Statior } & \multirow{2}{*}{ Parameter } & \multicolumn{4}{|c|}{ Duration, minutes } \\
\hline & & 15 & 20 & 25 & 30 \\
\hline \multirow{2}{*}{ 节 } & \begin{tabular}{|l|} 
Rainfall \\
intensity
\end{tabular} & $91 \pm 17.91^{\mathrm{d}}$ & $83.21 \pm 15.61^{\mathrm{c}}$ & $76.54 \pm 14.33^{b}$ & $71.35 \pm 13.56^{a}$ \\
\hline & 95\% C.I & 89.53-93.94 & $81.00 \pm 85.41$ & 74.34-78.74 & 69.14-73.55 \\
\hline \multirow{2}{*}{$\frac{\pi}{\frac{\pi}{\pi}}=$} & \begin{tabular}{|l|} 
Rainfall \\
intensity
\end{tabular} & $92.01 \pm 18.74^{a}$ & $83.73 \pm 16.52^{b}$ & $77.25 \pm 15^{c}$ & $71.91 \pm 14.21^{\mathrm{d}}$ \\
\hline & 95\% C.I & $91.81-92.21$ & $83.53-83.43$ & $77.05-77.45$ & $71.71 \pm 72.11$ \\
\hline \multirow{2}{*}{ 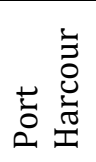 } & \begin{tabular}{|l|} 
Rainfall \\
intensity
\end{tabular} & $126.26 \pm 35.25^{a}$ & $111.58 \pm 29.91^{b}$ & $98.58 \pm 27.77^{c}$ & $92.00 \pm 23.47^{d}$ \\
\hline & $95 \%$ C.I & $125.12-127.40$ & $110.44-112.72$ & $97.44-99.72$ & $90.88-93.14$ \\
\hline \multirow{2}{*}{$\vec{\pi}^{\pi}$} & $\begin{array}{l}\text { Rainfall } \\
\text { intensity }\end{array}$ & $76.33 \pm 15.52^{\mathrm{a}}$ & $70.94 \pm 14.46^{b}$ & $66.57 \pm 13.86^{c}$ & $62.27 \pm 12.92^{\mathrm{d}}$ \\
\hline & 95\% C.I & 76.13-76.53 & 70.74-71.14 & $66.37-66.78$ & $62.09-62.49$ \\
\hline \multirow{2}{*}{$\begin{array}{l}\stackrel{\tilde{D}}{0}^{\sigma} \\
\stackrel{0}{0} \\
0\end{array}$} & $\begin{array}{l}\text { Rainfall } \\
\text { intensity }\end{array}$ & $77.91 \pm 16.04^{d}$ & $78.36 \pm 18.77^{c}$ & $79.02 \pm 18.26^{b}$ & $79.70 \pm 12.23^{a}$ \\
\hline & 95\% C.I & 77.71-78.11 & 78.16-78.56 & 78.82-79.22 & 79.59-79.90 \\
\hline
\end{tabular}

a-h indicate statistically significant difference 
It is shown that Equation types-1 and 2 produced maximum rainfall intensities (Table 4) than Equation types-3 and 4. Because IDF equations provide the basis for design of hydrological extreme events, this study therefore recommends the use of Equation Type- 1 as a preferred Equation type of IDF equation, because it predicts extreme intensities. Extreme rainfall intensities tend to reduce risk of protection against flooding.

\subsection{Discussion}

The observed trends agreed with the general curvature of rainfall intensity against duration which follows a logarithmic profile. Therefore, the greater return period of the storm of given duration, the higher the rainfall intensity.

Generally, the rainfall intensities increased with the return period in all the stations except Onitsha where the values at 35 and 40 years were lower (Table 2). This departure was probably due to the different physiographic setting of Onitsha. Furthermore, as the return period increased, the differences between successive predicted values become generally smaller (Table 2). A similar trend was also observed between rainfall intensity and duration (Table 3) and rainfall intensity and equation type (Table 4).

The study showed that two-parameter type- 2 equation provided overall lower ranges, while in terms of percent relative error, both type 1 and type- 2 provided the lowest values of less or equal to $6 \%$, within a return period of 15 years (Figs $2-6$ ). This is the return period usually adopted in the hydraulic design of structures. The study agreed with Froehlich [1] that the two-parameter type-2 equation provided nearly as good a fit as type- 3 and type- 4 respectively. And that the use of the simple type- 2 equation rather than the more accurate type- 3 or 4 , for intermediate duration rainfall seemed well justified. Furthermore, this study does not agree with the outright claim of superiority of type- 3 or 4 by Froehlich [1].

The plots of Figs 1a - e were ranked by assigning numerical values of 4 to the lowest range value (or least bar graph) and 1 to the highest range (tallest bar graph). The outcome of the ranking with respect to performance of each Equation type designated as Equations. 1 - 4 for the five cities are 19, 15, 12 and 5 points for equations types $1,2,3$ and 4 respectively. The order of best performance are Equation type- $1,1^{\text {st }}$ position followed by Equation type- 2 and the $4^{\text {th }}$ is Equation type-4, respectively.

The study by AlHassoun [12] found the power-law model to provide the best correlated and consistent relationships of analytical and derived curved for Riyadl area, especially for small duration and high return periods. The type of power-law equation derived by AlHassoun is a 3-parameter equation which is different from the 2-parameter type recommended in this study. Ogarekpe [10] recommended logarithmic IDF model over other models. The logarithmic IDF model is a special type of type- 2 equation.

Table 4: Predicted Rainfall Intensity by Equation Type

\begin{tabular}{|c|c|c|c|c|c|}
\hline \multirow[t]{2}{*}{ Statior } & \multirow{2}{*}{ Parameter } & \multicolumn{4}{|l|}{ Equation Type } \\
\hline & & EQ1 & EQ2 & EQ3 & EQ4 \\
\hline \multirow{2}{*}{ 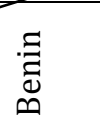 } & \begin{tabular}{|l|} 
Rainfall \\
intensity
\end{tabular} & $86.64 \pm 13.31^{\mathrm{a}}$ & $82.81 \pm 18.57^{b}$ & $76.34 \pm 16.73^{a}$ & $77.05 \pm 17.18^{c}$ \\
\hline & 95\% C.I & $86.44-86.84$ & $82.60-83.01$ & 76.14-76.55 & 76.84-77.35 \\
\hline \multirow{2}{*}{$\frac{\pi}{\frac{\pi}{\pi}}$} & $\begin{array}{l}\text { Rainfall } \\
\text { intensity }\end{array}$ & $89.05 \pm 12.49^{a}$ & $81.32 \pm 18.83^{b}$ & $76.32 \pm 14.47 c$ & $78.01 \pm 21.57^{\mathrm{d}}$ \\
\hline & 95\% C.I & $89.05-89.45$ & $81.12-81.52$ & $76.12-76.52$ & 77.81-78.21 \\
\hline \multirow{2}{*}{ 莒 } & \begin{tabular}{|l|} 
Rainfall \\
intensity
\end{tabular} & $128.80 \pm 32.35^{\mathrm{a}}$ & $102.34 \pm 27.24^{b}$ & $98.48 \pm 21.52^{c}$ & $98.80 \pm 35.50^{\mathrm{c}}$ \\
\hline & 95\% C.I & $127.65-124.93$ & $101.20-103.49$ & $97.34-99.63$ & $97.66-99.94$ \\
\hline \multirow{2}{*}{$\begin{array}{l}\bar{E} \\
3 \\
3\end{array}$} & \begin{tabular}{|l|} 
Rainfall \\
intensity
\end{tabular} & $70.20 \pm 11.10^{\mathrm{b}}$ & $63.99 \pm 12.87^{c}$ & $70.04 \pm 13.38^{b}$ & $71.90 \pm 20.36^{a}$ \\
\hline & 95\% C.I & $70.00-70.41$ & 63.78-64.19 & 69.84-70.24 & $71.70-78.11$ \\
\hline \multirow{2}{*}{$\begin{array}{l}\frac{\pi}{5} \\
\stackrel{⿹ \zh26}{\Xi} \\
0\end{array}$} & \begin{tabular}{|l|} 
Rainfall \\
intensity
\end{tabular} & $79.92 \pm 15.65^{c}$ & $77.26 \pm 16.72^{\mathrm{d}}$ & $77.56 \pm 16.85^{d}$ & $80.24 \pm 16.71^{c}$ \\
\hline & 95\% C.I & $79.72-80.12$ & $77.06-77.50$ & 77.37-77.77 & 80.04-80.44 \\
\hline
\end{tabular}

a-h indicate statistically significant difference 


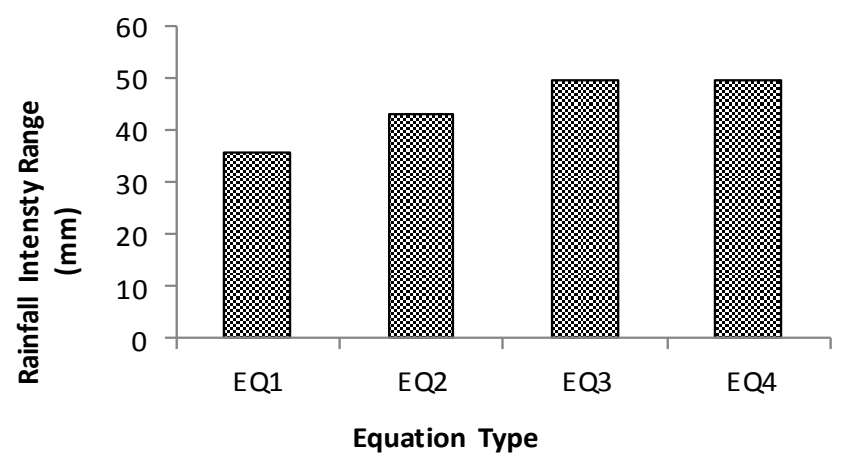

Fig. 1a: Range of Rainfall Intensity predicted by various equations at Benin

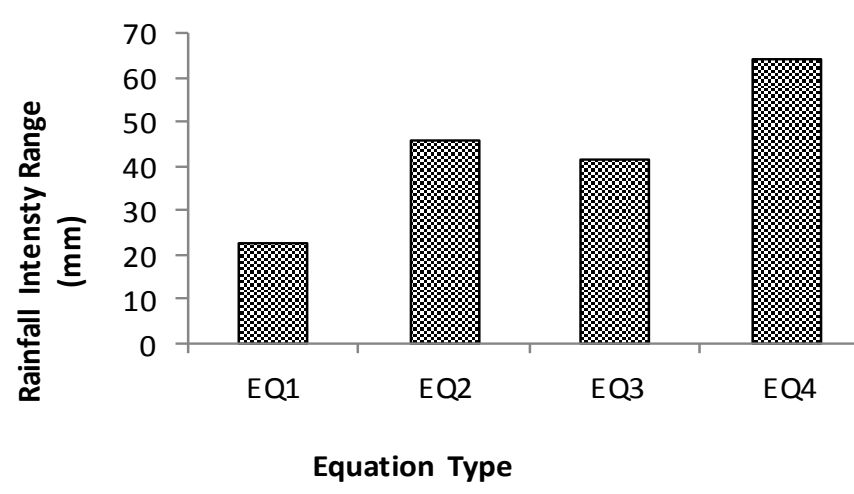

Fig. 1b: Range of Rainfall Intensity predicted by various equations at Calabar

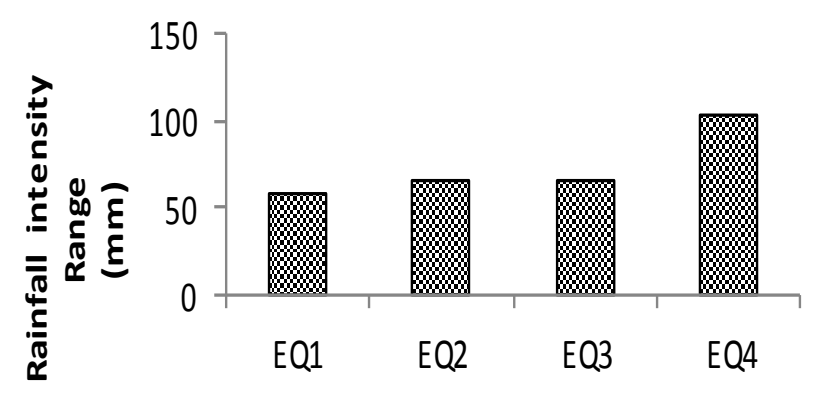

Equation Type

Fig. 1c Range of Rainfall Intensity predicted by various equations at Port Harcourt

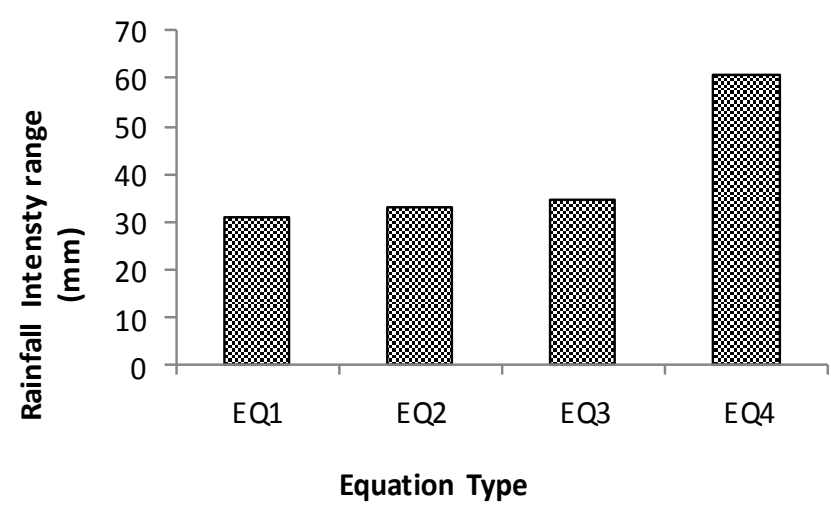

Fig. 1d: Range of Rainfall Intensity predicted by various equations at Warri

Nigerian Journal of Technology,

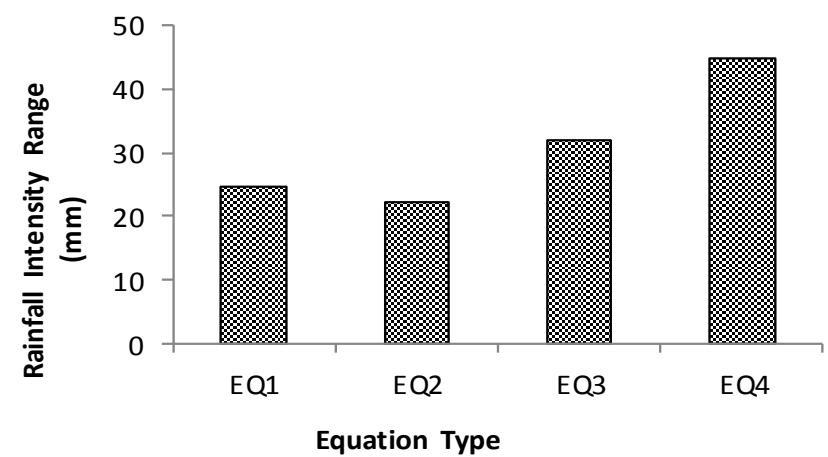

Fig. 1e: Range of Rainfall Intensity predicted by various equations at Onitsha

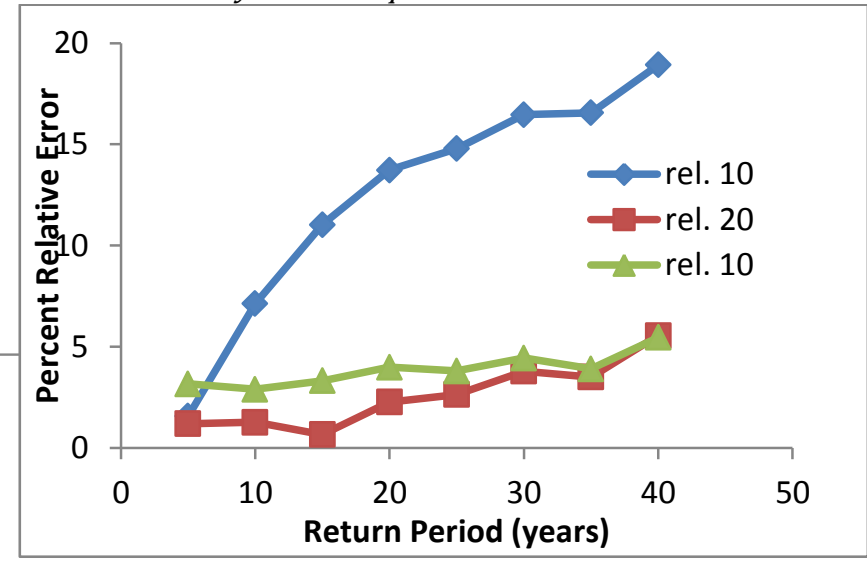

Fig. 2: Percent Relative error vs. Return Periods, IDF type 1. Benin

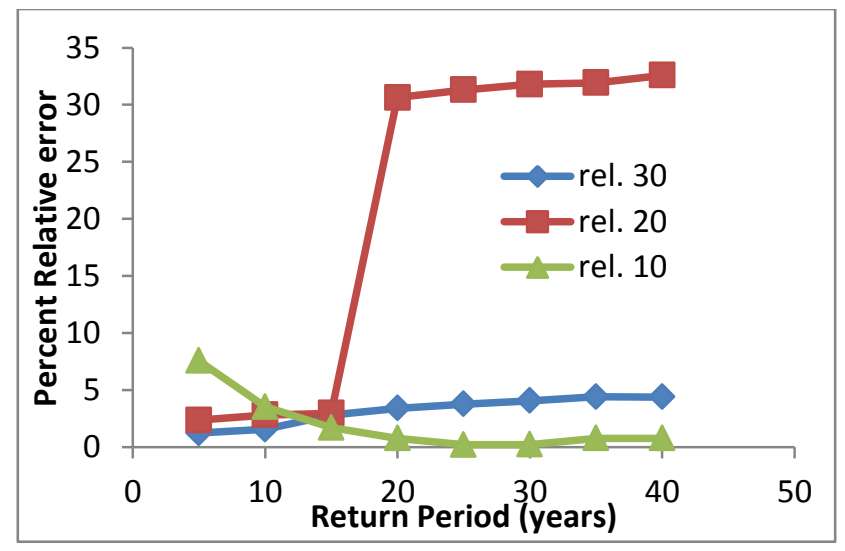

Fig. 3: Percent Relative Error vs. Return Periods, IDF type 2: Calabar

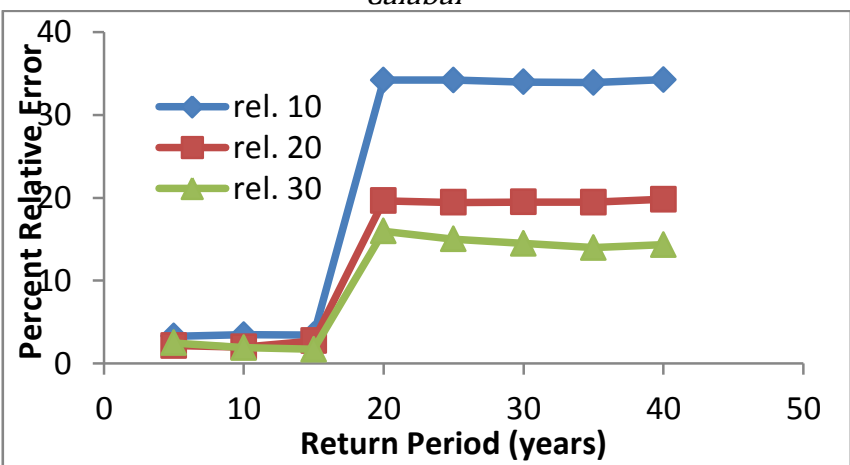

Fig. 4: Percent Relative Error vs. Return Periods, IDF type 2, Warri 


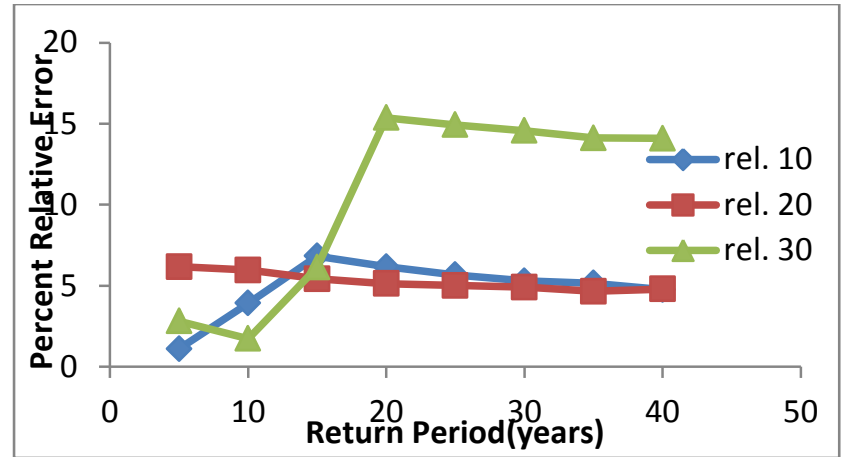

Fig. 5: Percent Relative Error vs. Return Periods, IDF type-2: Onitsha

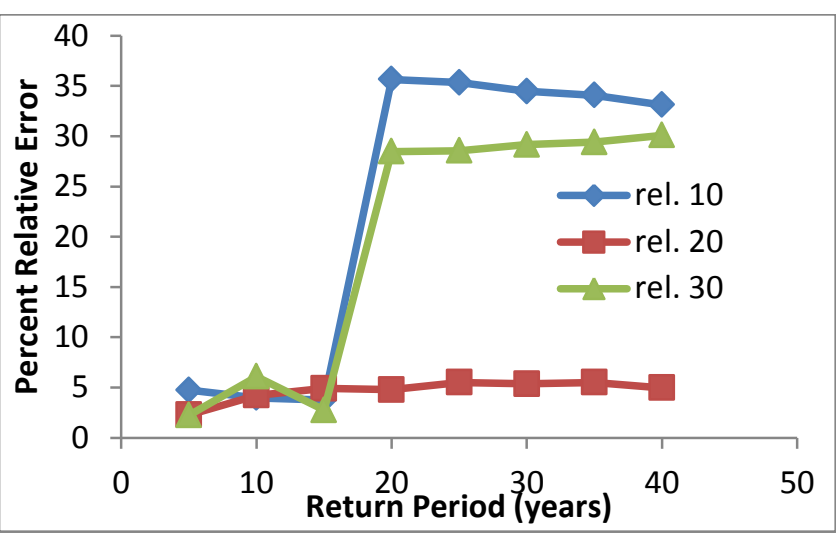

Fig. 6: Percent Relative Error vs. Return Periods, IDF type 2: Port Harcourt

\section{CONCLUSIONS}

The study has examined the four IDF equation types generally used in the hydrologic design of flood control structures. The study has shown that the IDF equation types globally used are different. There is significant difference $(\mathrm{F}<0.05)$ in rainfall intensity predicted even when the equation types were applied to stations having the same climate and physiographic setting. The study also found that equation type- 1 produced maximum rainfall intensities, followed by equation type- 2 and then equation type-3. Therefore Equation types 1 and 2 are recommended for hydrologic design and studies.

\section{REFERENCES}

[1] Froehlich, D.C. "Long-Duration-Rainfall Intensity Equation". Journal of Irrigation and Drainage Engineering, ASCE 121, No.3, 1975, pp248-252.

[2] Ministry of Health. Rainfall and Runoff. Journal of the Institution of Municipal Engineers Vol.56, 1930, pp1172 - 1176.

[3] Wenzel, H.G.. Rainfall for Urban Stormwater Design, In urban Storm Water Hydrology, edited by David F. Kibler. Water Resources Monograph 7, American Geophysical Union, Washington DC. 1972.
[4] Texas Department of Transportation, Hydraulic Manual, Bridge Division Austin, Tx, 1986.

[5] Awokola, 0. S. "Derivation of Rainfall IntensityDuration-Frequency (IDF) Equations for selected locations in Southern Nigeria" NSE Technical Transactions. Vol. 39, No.2, 2004.

[6] Nwaogazie, I. L. and Duru E. O. "Developing Rainfall Intensity-Duration-Frequency Model for Port Harcourt City." NSE Technical Transactions. Vol. 37, No. 2, 2002, pp. 19-32.

[7] Nwaogazie, I. L and Uba, L. O.. "Urban Drainage Failures and Incidence of flooding in Southern Nigeria". Nigerian Society of Engineers Technical Transaction, Vol. 33 (1), pp 33-42, 2001.

[8] Nwaogazie, I. L. and Okonkwo, S. C. "RainfallIntensity-Duration Frequency Modeling and Comparative Analysis of Developed Models for Abakiliki, Ebonyi State, Nigeria". Int'l Jour. of Trend in Research and Development, IJTRD Vol. 4(2), 2017. Available online @ www.ijtrd.com

[9] Ologhadien, I. "Analysis of Rainfall IntensityDuration-Frequency (IDF) Models for Design of Flood Control Structure". Journal of Applied Science and Technology Vol. 13, Nos. 1 \& 2, 2008, pp. $104-107$.

[10] Ogarekpe, N. M. "Development and Comparison of Different Intensity Duration Frequency Model for Calabar, Nigerian Journal of Technology, Vol. 33, No.1, 2014, pp33 - 42.

[11] Udomboso. C. G. and Amahia, G. N. "Comparative Analysis of Rainfall Prediction using Statistical Neutral and Classical Linear Regression Model". Journal of Modern Mathematics and Statistics, Vol. 5, No.3, 2011, pp66 - 70.

[12] AlHassoun, A. S. "Developing an empirical formulae to estimate rainfall Intensity in Riyadh region". Journal of King Saud University Engineering Science. Vol. 23, 2011, pp. 81 - 88 .

[13] Okonkwo G. I. and Mbajiorgu, C. C. "Rainfall Intensity-Duration-Frequency Analysis for South Eastern Nigeria". Agricultural Engineering International: the CIGRE Journal. Manuscript 1304, Vol. XII, 2010.

[14] Bernard, M. M. "Formulas for rainfall intensities of long duration". Transactions, ASCE, 96 (Paper No.1801), 1932, pp.592-624.

[15] Eze, H. I. "Effect of rainfall intensity and energy on gully development in northeastern Enugu State, Nigeria". Nigerian Journal of Technology, Vol. 26, No.1, 2007, pp. 91-96.

[16] El-Sayed, E. A. "Generation of Rainfall Intensity Duration Frequency Curves for Ungauged Sites". Nile Basin Water Science \& Engineering Journal, 4(1), 2011, pp. 112-124.

[17] Ologhadien, I. and Nwaogazie I. "RainfallIntensity-Duration Models for selected cities in Southern Nigeria". Standard Scientific Research and Essays, Vol. 2, No.10, 2014, pp. 509 - 515. 